\title{
In That Case
}

\author{
Malcolm Parker
}

Received: 14 March 2010 / Accepted: 19 March 2010/Published online: 31 March 2010

(C) Springer Science+Business Media B.V. 2010

\section{Call for Responses}

The case outlined below will be the basis for the In That Case section in the next issue of the Journal of Bioethical Inquiry $(J B I)$. We invite interested readers to provide responses to the case for possible publication. Responses should be 500-700 words, and should be submitted as soon as possible after publication of this issue. The editors will select the responses to be published in the next issue of the $J B I$, and reserve the right o edit contributions to avoid repetition. Editorial changes will be cleared with authors before going to press. Responses should be submitted on Editorial Manager.

\section{Two Concepts of Dignity and Integrity}

On March 9, the Sydney Morning Herald reported the case of Angela, an 11 year old girl with Rett syndrome, who is profoundly disabled. She is considered to behave similarly to a 3 month old baby. She is unable to talk, has to be fed, has no bladder control, and has epilepsy. Although her seizures were controlled by medication, they continued to break through with heavy menstrual periods. Doctors recommended a hysterectomy, which under Australian

M. Parker $(\square)$

School of Medicine, University of Queensland,

Brisbane, Australia

e-mail: m.parker@uq.edu.au law requires a court order, usually from the Family Court. Family Court Judge Paul Cronin reasoned that the hysterectomy was urgent and necessary, and would be in Angela's best interests on grounds of risks to her life and considerations of her general health.

Some disability groups have supported the decision, including on the grounds of the right to human dignity, but other commentators have denounced it as abusing the right of a disabled person to respect for her bodily integrity.

A number of questions come to mind. Is human dignity a helpful concept with which to deliberate about cases such as Angela's? What is the moral relevance of bodily integrity here? Is it a matter of both supportive and critical comments on the case being correct, but of one being more rationally, or emotionally, or "humanly" compelling than the other? And can the concepts of dignity and integrity be put to work in relation to the interests of Angela's parents, as well as Angela? Other questions no doubt arise.

\section{References}

Osborne, P. Disabled girl can be sterilised. Sydney Morning Herald, 9 March 2010. Available at http://news.smh.com. au/breaking-news-national/disabled-girl-can-be-sterilisedcourt-20100309-pu61.html, accessed 15 March 2010.

RE: ANGELA (SPECIAL MEDICAL PROCEDURE) [2010] FamCA 98. Available at http://www.familycourt.gov.au/wps/ wcm/resources/file/eb204741 ce4e7c0/2010_FamCA_98.pdf, accessed 15 March 2010. 